\title{
Bioluminometric Method for Real-Time Detection of ATPase Activity
}

BioTechniques 31:420-425 (August 2001)

\author{
Samer Karamohamed and \\ Guido Guidotti \\ Harvard University, Cambridge, \\ MA, USA
}

\section{INTRODUCTION}

Ectoapyrases and ecto-ATPases are members of the ecto-nucleoside triphosphate diphosphohydrolase (ENTDPase) family of enzymes (25). ENTDPases are strictly dependent on divalent cations for activity and are generally insensitive to the specific inhibitors of P-type (ouabain and vanadate), F-type (azide, oligomycin, and dicyclohexylcarbodiimide) and V-type (N-ethylmaleimide and NBD-Cl) ATPases $(20,32)$. Ectoapyrases are distinguished from ecto-ATPases by their ability to hydrolyze both nucleoside triand diphosphates and their inhibition by $10-20 \mathrm{mM}$ azide (25). E-NTDPases have been isolated and studied from animal sources and organisms such as rat secretory tissue (30), rat hepatocytes $(21,22)$, rabbit skeletal muscle transverse tubules (29), bovine lung (24), Toxoplasma gondii (4), and yeast (26). They have also been isolated from plant tissues such as pea stem (27), chick-pea root $(31)$, and potato tuber $(15,16)$. Apyrases isolated from Solanum tuberosumare among the most extensively studied apyrases, and several isoforms have been isolated (17). It has been suggested that E-NTDPases participate in neurotransmission (5), blood platelet aggregation and blood pressure regulation (23), protein glycolysation (1), and the regulation of membrane integrity (8). The molecular properties of this family of enzymes have been recently described (33).

Both colorimetric- and radioisotopebased methods have been developed and used for the detection of ATPase activity, based on the measurement of the product released from the apyrase reaction, either orthophosphate or ADP $(2,6,9,19,28)$.

$$
\stackrel{\text { Apyrase }}{\text { ATP } \rightarrow \mathrm{ADP}}+\mathrm{P}_{\mathrm{i}} \rightarrow \mathrm{AMP}+\mathrm{P}_{\mathrm{i}}
$$

Interestingly, the coupled reaction that links ADP production to NADH oxidation (3) has not been used with the E-NTPDases, although it is capable of measuring the activity of $50 \mathrm{mU}$ enzymatic activity.

Most of these methods are labor intensive, require time-consuming procedures, and do not detect the ATPase activity in real time. Here, we describe a simple and sensitive technique for the detection of ATPase activity in real time using the luciferase/luciferin system.

\section{MATERIALS AND METHODS}

\section{Real-Time ATPase Method}

The standard assay volume $(0.2 \mathrm{~mL})$ contained the following components: $0.1 \mathrm{M}$ Tris-acetate, $\mathrm{pH}$ 7.75, $2 \mathrm{mM}$ EDTA, $10 \mathrm{mM}$ magnesium acetate, $0.1 \%$ BSA, $1 \mathrm{mM}$ DTT, $0.4 \mathrm{mg} / \mathrm{mL}$ polyvinylpyrrolidone $\left(\mathrm{M}_{\mathrm{r}}=360000\right)$, $100 \mu \mathrm{g} / \mathrm{mL}$ D-luciferin (the last four products were from Sigma, St. Louis, MO, USA), and purified luciferase (Promega, Madison, WI, USA) in an amount giving a response of $10 \mathrm{mV}$ for $0.1 \mu \mathrm{M}$ ATP (about $3 \mathrm{ng}$ luciferase). After the addition of potato apyrase (Sig$\mathrm{ma}$ ), the reaction was initiated by the addition of 100 pmol ATP. The luminescence was measured using a LKB 1250 tube luminometer connected to a poten- 
Table 1. The Effect of Various Inhibitors on the Potato Apyrase-Catalyzed ATPase Activity

\begin{tabular}{|c|c|c|c|c|c|c|c|c|c|}
\hline \multicolumn{2}{|c|}{$\mathrm{NaN}_{3}$} & \multicolumn{2}{|c|}{$\mathbf{P}_{\mathbf{i}}$} & \multicolumn{2}{|c|}{ AMP } & \multicolumn{2}{|c|}{ ADP } & \multicolumn{2}{|c|}{$\mathrm{NaF}$} \\
\hline $\begin{array}{l}\text { Conc. } \\
\text { (M) }\end{array}$ & $\begin{array}{l}\text { R.A. } \\
(\%)\end{array}$ & $\begin{array}{l}\text { Conc. } \\
\text { (mM) }\end{array}$ & $\begin{array}{l}\text { R.A. } \\
(\%)\end{array}$ & $\begin{array}{l}\text { Conc. } \\
(\mathrm{mM})\end{array}$ & $\begin{array}{l}\text { R.A. } \\
\text { (\%) }\end{array}$ & $\begin{array}{c}\text { Conc. } \\
(\mu \mathrm{M})\end{array}$ & $\begin{array}{l}\text { R.A. } \\
\text { (\%) }\end{array}$ & $\begin{array}{l}\text { Conc. } \\
\text { (mM) }\end{array}$ & $\begin{array}{l}\text { R.A. } \\
(\%)\end{array}$ \\
\hline 0 & 100 & 0 & 100 & 0 & 100 & 0 & 100 & 0 & 100 \\
\hline 0.1 & 50 & 0.005 & 93 & 0.05 & 80 & 2.5 & 80 & 0.01 & 90 \\
\hline 0.16 & 40 & 0.025 & 75 & 0.125 & 64 & 5 & 72 & 0.045 & 60 \\
\hline 0.4 & 20 & 0.125 & 50 & 0.25 & 50 & 25 & 40 & 0.115 & 37.5 \\
\hline \multirow[t]{3}{*}{1.2} & 9 & 0.5 & 25 & 0.5 & 35 & 75 & 20 & & \\
\hline & & 2.5 & 8 & 2.5 & 8.3 & & & & \\
\hline & & & & 5 & 1 & & & & \\
\hline $\begin{array}{l}\text { There } w \\
\text { and the } \\
\text { and rep } \\
\text { Method }\end{array}$ & $\begin{array}{l}\text { re } 7 \mathrm{ml} \\
\text { ercenta } \\
\text { sents }\end{array}$ & $\begin{array}{l}\text { and } 100 \\
\text { pyrase- } \\
\text { value } \mathrm{fr}\end{array}$ & $\begin{array}{l}\text { hol of } A \\
\text { alyzed } \\
\text { sever }\end{array}$ & $\begin{array}{l}\text { ch react } \\
\text { drolysis } \\
\text { nents. }\end{array}$ & $\begin{array}{l}n \text {. The } t \\
\text { tivity }(R \\
\text { e exper }\end{array}$ & $\begin{array}{l}\text { ws the } \\
\text { ch point } \\
\text { condition }\end{array}$ & $\begin{array}{l}\text { centrat } \\
\text { s obtair } \\
\text { vere as }\end{array}$ & $\begin{array}{l}\text { ach inhib } \\
\mathrm{n} \text { individu } \\
\text { sed in } \mathrm{Ma}\end{array}$ & $\begin{array}{l}\text { r (Conc } \\
\text { assays } \\
\text { erials anc }\end{array}$ \\
\hline
\end{tabular}

tiometric recorder, and the luminometer was calibrated to give a response of 10 $\mathrm{mV}$ for the luminometer internal standard.

To study the effects of vanadate (0-0.5 mM), azide $(0-1.25 \mathrm{M})$, fluoride $\left(\mathrm{F}^{-}\right)(0-0.11 \mathrm{mM})$, AMP $(0-5 \mathrm{mM})$, and $\mathrm{P}_{\mathrm{i}}(0-2.5 \mathrm{mM})$ (all inhibitors were from Sigma Chemical), several assays were performed. The inhibitor and $7 \mathrm{mU}$ apyrase, one unit liberates $1 \mu \mathrm{mol}$ $\mathrm{P}_{\mathrm{i}} / \mathrm{min}$ at $30^{\circ} \mathrm{C}$, were preincubated in the standard assay mixture before the reaction was started by the addition of 100 pmol ATP and the luminescence was recorded. To study the effect of ADP (0-0.1 mM), several assays were performed. The standard assay used was as previously described, with the exception that the reaction was started by the addition of both ATP and ADP (contaminated with ATP) so that the total amount of ATP in the reaction was 100 pmol. The effect of the inhibitor on the

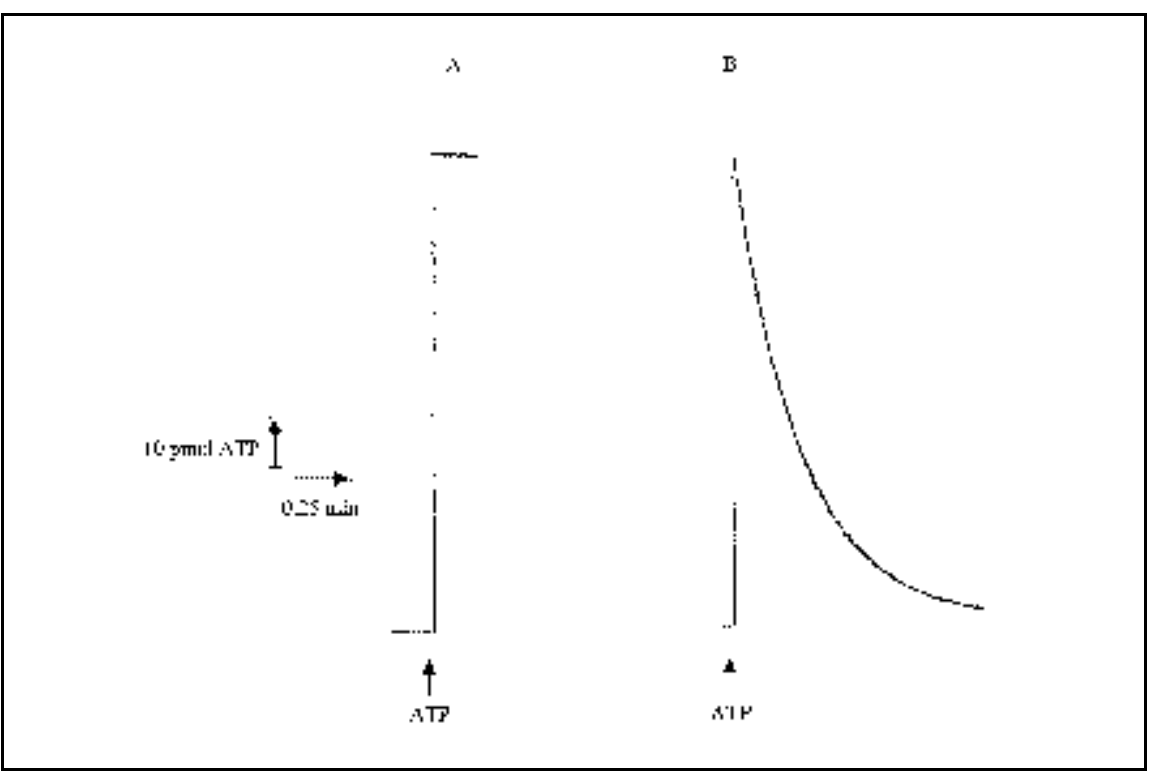

Figure 1. Typical traces from real-time monitoring of apyrase activity. Apyrase was either omitted (A) or preincubated (B) in the assay mixture before the reactions were started by the addition of 100 pmol ATP at a final concentration of $0.5 \mu \mathrm{M}$. The ATP degradation was detected by the luciferase system. The experimental conditions were as described in Materials and Methods. luciferase reaction was established by measuring the light yield of ATP in the presence of the inhibitor (Figure 1A); in all cases, the inhibitors did not affect the reaction of luciferase with ATP.

\section{RESULTS}

\section{Real-Time Detection of ATPase Activity}

Potato apyrase (or any enzymatic activity that hydrolyzes ATP) is preincubated with the reaction mixture before the reaction is started by the addition of ATP. The assay reactions are shown below.

$$
\begin{gathered}
\mathrm{ATP}+\text { luciferin }+\mathrm{O}_{2} \stackrel{\text { Luciferase }}{\rightarrow} \mathrm{AMP}+ \\
\mathrm{PP}_{\mathrm{i}}+\text { Oxyluciferin }+\mathrm{CO}_{2}+\mathrm{hv}
\end{gathered}
$$

$$
\mathrm{ATP} \stackrel{\text { Apyrase }}{\rightarrow} \mathrm{ADP}+\mathrm{P}_{\mathrm{i}}
$$

The concentration of ATP was determined by the luciferase reaction (Figure 1A) [Eq. 2]. Under our assay conditions, the amount of light produced is proportional to the concentration of ATP in the range of $10 \mathrm{pM}-1$ $\mu \mathrm{M}$. At higher concentrations of ATP, the reaction is complicated by the inhibition of the luciferase by oxyluciferin (7). The amount of ATP consumed in the luciferase reaction is negligible because the light emission is constant 
over a period of more than $10 \mathrm{~min}$. The activity of potato apyrase was measured as the decrease in the ATP concentration detected by luminescence as a function of time (Figure 1B). The loss of ATP appears to follow an exponential curve. When these data were fitted with the software program "Igor" (WaveMetrics, Lake Oswego, OR, USA), the decay curve appeared to be an exponential curve with a value of $\mathrm{k}_{\mathrm{app}}=0.0991 \mathrm{~s}^{-1}$ (Figure 2).

Because the $K_{m}$ value for ATP of potato apyrase is $200 \mu \mathrm{M}(25)$ and the concentration of ATP in the experiment was $500 \mathrm{nM}$, the kinetic equation for the enzymatic reaction:

$$
\begin{gathered}
\text { Apyrase + ATP } \underset{\mathrm{k}_{-1}}{\stackrel{\mathrm{k}_{1}}{\leftrightarrow}} \text { Apyrase.ATP } \\
\stackrel{\mathrm{k}_{\text {cat }}}{\leftrightarrow} \text { Apyrase + ADP }
\end{gathered}
$$

is the first order part of the MichaelisMenten equation. The initial rate, $v$, is given by

$v=\frac{-d(S)}{d t}=(S)($ Etot $) \frac{k_{c a t}}{K_{m}}$

where (S) is the concentration of ATP, (Etot) is the total apyrase concentration, and $\mathrm{K}_{\mathrm{m}}$ and $\mathrm{k}_{\text {cat }}$ have the usual significance. The decay of the substrate concentration $(\mathrm{S})$ is given by

$$
(S)=(\text { So }) e^{-\left((\text {Etot }) k_{\text {cat }}\right) t} \frac{-K_{m}}{K_{m}}=(\text { So }) e^{-k a p p . t}
$$

where $(S o)$ is the initial concentration of ATP and

$k_{\text {app }}=($ Etot $) \frac{k_{\text {cat }}}{K_{m}}$

Because $t_{0.5}=\frac{0.693}{k_{a p p}}$ for a first-order reaction, we report the values of $t_{0.5}$ for the reactions.

\section{Effect of ATP Concentration}

We used this method to study the effect of ATP concentration on the ATPase reaction catalyzed by apyrase. Figure 3 shows $v$ (from equation 5) for ATP degradation catalyzed by apyrase as a function of the ATP concentration; $\mathrm{v}$ is directly proportional to ATP, between 0 and $500 \mathrm{nM}$.

On the basis of this experiment, ATP at a final concentration of $500 \mathrm{nM}$ was chosen as an optimal concentration for the sensitive detection of ATPase activity. The ATP decay rate was proportional to the amount of apyrase, as predicted by Eq. 7 (Figure 4). Using this method, we were able to detect ATPase activity from potato apyrase between 0.7 and $70 \mathrm{mU}$. Because the rate of consumption of ATP by luciferase is very slow (Figure 1A), it is possible to measure the activity of $0.07 \mathrm{mU}$ apyrase $\left(t_{0.5}=\right.$ approximately $\left.3 \mathrm{~min}\right)$. It is worth noting that the unit is defined for a reaction performed at $30^{\circ} \mathrm{C}$ and $\mathrm{pH} 6.5$ for the potato apyrase, whereas our experiments were performed at room temperature, about $22^{\circ} \mathrm{C}$, and $\mathrm{pH} 7.75$.

\section{Inhibition of the ATPase Activity by Vanadate and Other Inhibitors}

This method can be used to study the effects of different substrates on the ATPase activity. For example, vanadate is not known to inhibit ectoapyrase activity; however, we have detected an inhibitory effect of vanadate on the ATPase activity of apyrase from $S$. tuberosum(Figure 5). Nearly 50\% inhibition was obtained at a concentration of about $20 \mu \mathrm{M}$. At $0.5 \mathrm{mM}$ vanadate, about $98 \%$ inhibition of the apyrase ATPase activity was observed (Figure 6). The assay has also been used to

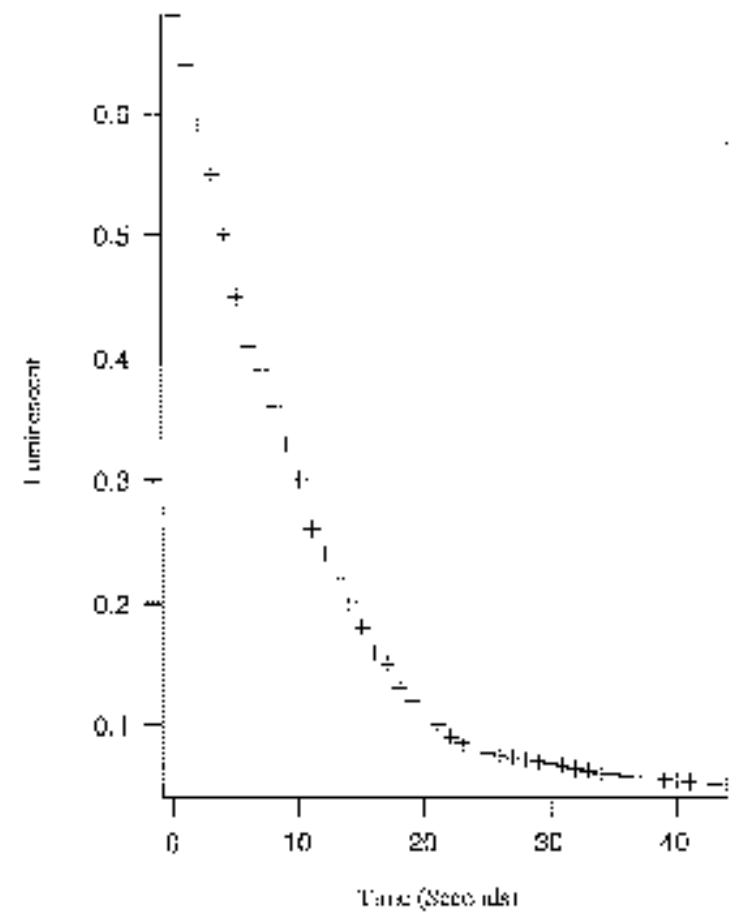

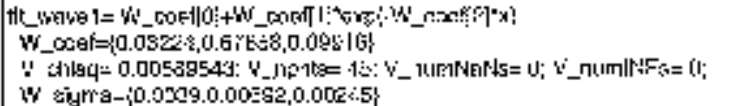

Figure 2. The apyrase ATPase activity as a function of time. The reactions were started by the addition of $100 \mathrm{pmol}$ ATP to an assay mixture containing $7 \mu \mathrm{U} S$. tuberosumapyrase. The ATP degradation was detected by the luciferase system. Each point was obtained from individual assays and represents an average value from several experiments. The data were fit with the equation shown in the caption with the Igor program: fit_wave1 is the value of luminescence at time $t, \mathrm{~W} \_$coef[1] is the initial value of luminescence, $\mathrm{W}_{-}$coef $[2]$ represents $\mathrm{k}_{\mathrm{app}}$, and $\mathrm{W} \_$coef[0] is the residual fluorescence at the end of the reaction. The values of W_coef are given in the second line of the caption, and the statistical values of the fit are given in lines 3 and 4 . The experimental conditions were as described in Materials and Methods. 
study the effect of other inhibitors on the ATPase activity of the potato apyrase (Table 1). The $\mathrm{IC}_{50}$ for azide, AMP, $\mathrm{P}_{\mathrm{i}}, \mathrm{F}^{-}$, and ADP were found to be approximately $100,0.25,0.125,0.04$, and $0.035 \mathrm{mM}$, respectively. In contrast, with the conventional assay, $2 \mathrm{mM} \mathrm{F}^{-}$ and $0.2 \mathrm{mM}$ vanadate had no effect on the ATPase activity of chicken oviduct ecto-ATPDase, while $10 \mathrm{mM}$ azide inhibited $70 \%-74 \%$ of the activity (18).

\section{DISCUSSION}

Generally, bioluminescence-based techniques have several advantages over commonly used methods, such as speed, simplicity, and sensitivity. Therefore, new bioluminescence-based methods continue to be developed (1214). Here, we present a bioluminometric approach for the real-time detection and quantification of ATPase activity.

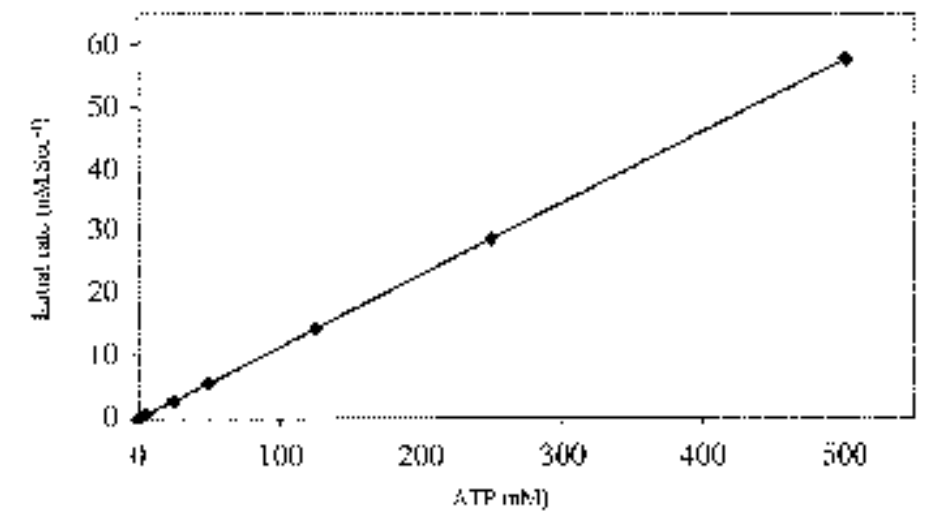

Figure 3. The initial rate of apyrase-catalyzed ATP degradation as a function of the ATP concentration. The reactions were started by the addition of the ATP (at the indicated final concentration) to an assay mixture containing $7 \mu \mathrm{U} S$. tuberosumapyrase. The ATP degradation was detected by the luciferase system. Each point was obtained from individual assays and represents an average value from several experiments.

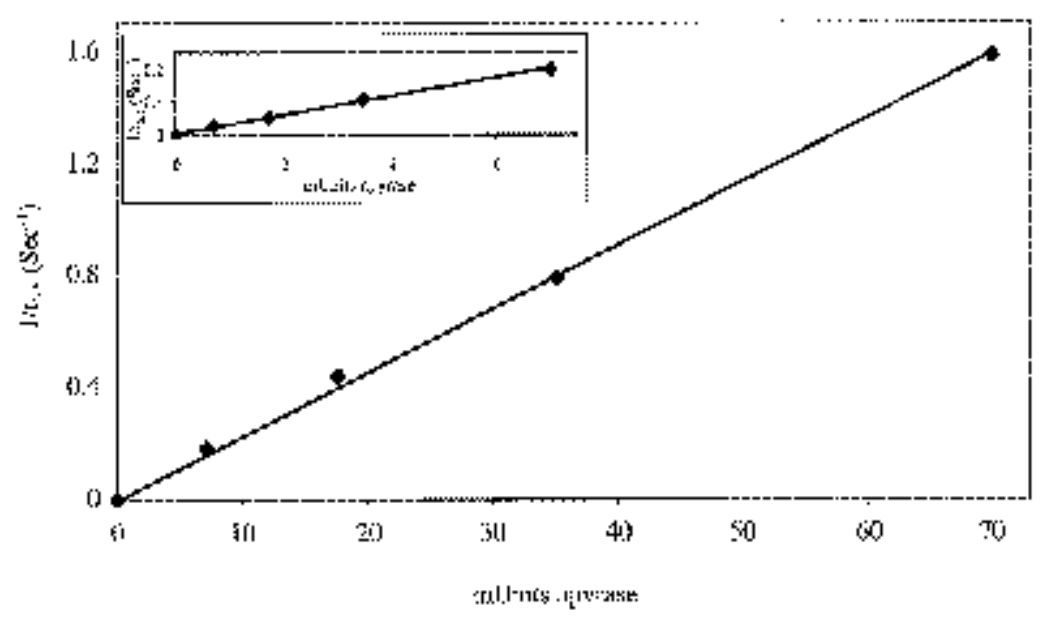

Figure 4. Apparent rate constant $\left(k_{\text {app }}\right)$ of apyrase-catalyzed ATP hydrolysis as a function of the apyrase amount. The reactions were started by the addition of 100 pmol ATP to an assay mixture containing the indicated amount of apyrase. ATP hydrolysis was detected by the luciferase system. Each point was obtained from individual assays and represents an average value from several experiments. In the inset, the $\mathrm{k}_{\mathrm{app}}$ obtained at low apyrase concentrations are shown. The experimental conditions were as described in Materials and Methods. 


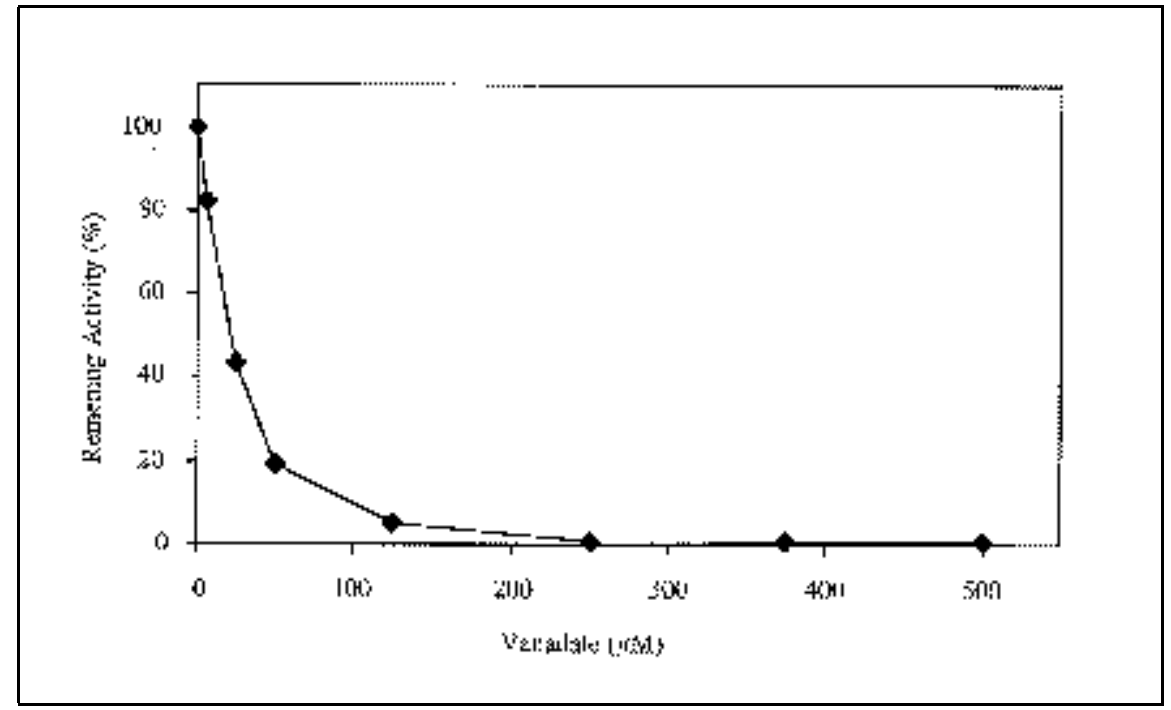

Figure 5. The apyrase ATPase activity as a function of vanadate concentration. Apyrase and vanadate were preincubated in the reaction mixture. The reaction was started by the addition of ATP at a final concentration of $0.5 \mu \mathrm{M}$. The ATP hydrolysis was detected by the luciferase system. Each point was obtained from individual assays and represents an average value from several experiments. One hundred percent represents the maximum value of apyrase ATPase activity in the absence of vanadate. The experimental conditions were as described in Materials and Methods.

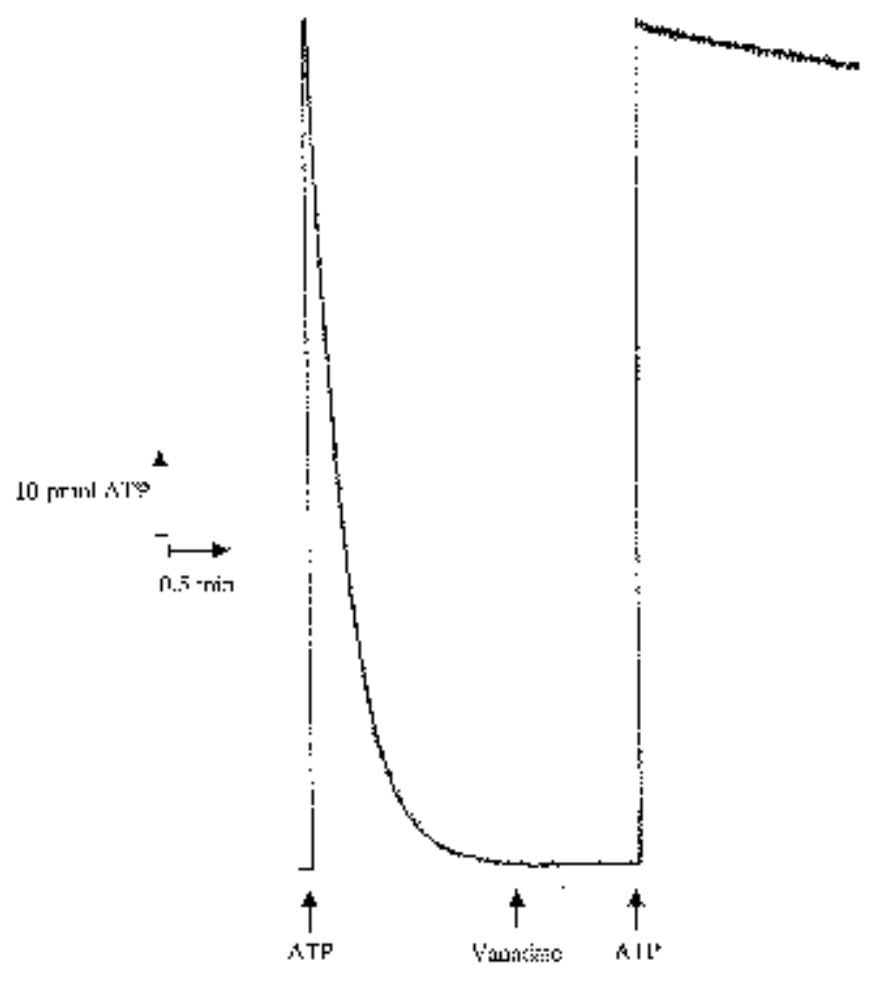

Figure 6. Typical trace obtained from real-time monitoring of the inhibitory effect of vanadate on the apyrase-catalyzed ATPase activity. ATP $(100 \mathrm{pmol})$ was added in the presence of $7 \mu \mathrm{U}$ apyrase. When almost all of the added ATP had been hydrolyzed by apyrase, vanadate at a final concentration of $300 \mu \mathrm{M}$ was added. ATP $(100 \mathrm{pmol})$ was then added to the reaction. ATP hydrolysis was detected by the luciferase system. The experimental conditions were as described in Materials and Methods.
Similar to most of the luminescent assays, this is a simple, one-step method involving the addition of apyrase to the reagents. There is no need for incubation steps or the addition of stopping or developing solutions. The reaction can be completed within a minute, which allows fast analysis of many samples.

The real-time ATPase approach has a broad dynamic range, and the detection limit is approximately $0.7 \mathrm{mU}$ potato apyrase. The sensitivity of the assay can be increased by performing the reaction in a smaller volume. At present, the assay is performed at room temperature because of the temperature sensitivity of the luciferase. However, the method's sensitivity can be increased by using a more thermostable luciferase $(10,11)$ and by performing the assay at a higher temperature, which allows the optimal temperature for the apyrase.

The method has many possible applications, such as the determination of the specific activity for different enzyme batches and for the study of the effects of different inhibitors on the ATPase activity (Table 1). Furthermore, the developed method was used for the detection and quantification of both recombinant 5'-nucleotidase and CD39 ATPase activity during both the production and purification of the enzymes (data not shown). The method has also been used during the purification of potato apyrase (data not shown).

In this study, the real-time monitoring of the ATPase activity was performed with an LKB single-tube luminometer. However, by using a microplate-format luminometer, the capacity of the technique can be further increased.

In conclusion, a simple, real-time, nonradioactive method for the continuous measurement of ATPase activity has been developed. The method offers the possibility of studying the ATPase activity from different sources (e.g., ectoapyrases) in real time.

\section{ACKNOWLEDGMENTS}

The authors thank Dr. Pål Nyrén and Jonas Erikson (Royal Institute of Technology, Stockholm, Sweden) for their help with the inhibition experiments. This work was supported by National Institutes of Health grant no. HL08893 to G.G. 


\section{REFERENCES}

1.Abeijon, C., K. Yanagisawa, E.C. Mandon, A. Hausler, K. Moremen, C.B. Hirschberg, and P.W. Robbins. 1993. Guanosine diphosphatase is required for protein and sphingolipid glycosylation in the Golgi lumen of Saccharomyces cerevisiae. J. Cell. Biol. 122:307-323.

2.Baginski, E.S., E. Epstein, and B. Zak. 1975. Review of phosphate methodologies. Ann. Clin. Lab. Sci. 5:399-416.

3.Barnett, R.E. 1970. Effect of monovalent cations on the ouabain inihibition of the sodium and potassium ion activated adenosine triphosphatase. Biochemistry 9:4644-4648.

4.Bermudes, D.K., R. Peck, M.A. Afifi, C.J. Beckers, and K.A. Joiner. 1994. Tandemly repeated genes encode nucleoside triphosphate hydrolase isoforms secreted into the parasitophorous vacuole of Toxoplasma gondii. J. Biol. Chem. 269:29252-29260.

5.Edwards, F.A. and A.J. Gibb. 1993. ATP-a fast neurotransmitter. FEBS Lett. 325:86-89.

6.Fiske, C.H. and Y. SubbaRow. 1925. The colorimetric determination of phosphorus. J. Biol. Chem. 66:375-400.

7.Ford, S.R., K.H. Chenault, L.S. Bunton, G.J. Hampton, J. McCarthy, M.S. Hall, S.J. Pangburn, L.M. Buckand et al. 1996. Use of firefly luciferase for ATP measurement: other nucleotides enhance turnover. J. Biolumin. Chemilumin. 11:149-167.

8.Girolomoni, G., M.L. Santantonio, S. Pastore, P.R. Bergstresser, A. Giannetti, and P.D. Cruz, Jr. 1993. Epidermal Langerhans cells are resistant to the permeabilizing effects of extracellular ATP: in vitro evidence supporting a protective role of membrane ATPase. J. Invest. Dermatol. 100:282-287.

9.Hess, H.H. and J.E. Derr. 1975. Assay of inorganic and organic phosphorus in the $0.1-5$ nanomole range. Anal. Biochem. 63:607-613.

10.Kajiyama, N. and E. Nakano. 1993. Thermostabilization of firefly luciferase by a single amino acid substitution at position 217. Biochemistry 32:13795-13799.

11.Kajiyama, N. and E. Nakano. 1994. Enhancement of thermostability of firefly luciferase from Luciola lateralis by a single amino acid substitution. Biosci. Biotechnol. Biochem. 58:1170-1171.

12.Karamohamed, S., T. Nordström, and P. Nyrén. 1999. Real-time bioluminometric method for detection of nucleoside diphosphate kinase activity. BioTechniques 26:728734.

13.Karamohamed, S. and P. Nyrén. 1999. Real-time detection and quantification of adenosine triphosphate sulfurylase activity by a bioluminometric approach. Anal. Biochem. 271:81-85.

14.Karamohamed, S., M. Ronaghi, and P. Nyrén. 1998. A bioluminometric method for real-time detection of reverse transcriptase activity. BioTechniques 24:302-306.

15.Kettlun, A.M., M. Leyton, M.A. Valenzuela, M. Mancilla, and A. Traverso-Cori. 1992. Identification and subcellular localization of two isoenzymes of apyrase from Solanum tuberosum Phytochemistry 31:1889-9184.
16.Kettlun, A.M., L. Uribe, S. Calvo, S. Silva, J. Rivera, M. Mancilla, M.A. Valenzuela, and A. Traverso-Cori. 1982. Properties of two apyrases from Solanum tuberosum Phytochemistry 3:551-558.

17.Kettlun, A.M., R. Urra, M. Leyton, M.A. Valenzuela, M. Mancilla, and A. TraversoCori. 1992. Purification and characterization of two isoapyrases from Solanum tuberosum var. Ultimús. Phytochemistry 31:3691-3696.

18.Knowles, A.F. and A.K. Nagy. 1999. Inhibition of an ecto-ATP-diphosphohydrolase by azide. Eur. J. Biochem. 262:349-357.

19.Lanzetta, P.A., L.J. Alvarez, P.S. Reinach, and O.A. Candia. 1979. An improved assay for nanomole amounts of inorganic phosphate. Anal. Biochem. 100:95-97.

20.Lin, S.H. 1985. The rat liver plasma mem brane high affinity (Ca2+-Mg2+)-ATPase is not a calcium pump. Comparison with ATP dependent calcium transporter. J. Biol. Chem. 260:10976-10980.

21.Lin, S.H. 1989. Localization of the ecto-ATPase (ecto-nucleotidase) in the rat hepatocyte plasma membrane. Implications for the func tions of the ecto-ATPase. J. Biol. Chem 264:14403-14407.

22.Lin, S.H. and G. Guidotti. 1989. Cloning and expression of a cDNA coding for a rat liver plasma membrane ecto-ATPase. The primary structure of the ecto-ATPase is similar to that of the human biliary glycoprotein I. J. Biol. Chem. 264:14408-14414.

23.Marcus, A.J. and L.B. Safier. 1993. Throm boregulation: multicellular modulation of platelet reactivity in hemostasis and thrombosis. FASEB J. 7:516-522.

24.Picher, M., Y.P. Cote, R. Beliveau, M. Potier, and A.R. Beaudoin. 1993. Demonstration of a novel type of ATP-diphosphohydrolase (EC 3.6.1.5) in the bovine lung. J. Biol. Chem. 268:4699-4703.

25.Plesner, L. 1995. Ecto-ATPases: identities and functions. Int. Rev. Cytol. 158:141-214.

26. Rothstein A. and R. Meier. 1984. The relationship of the cell surface to metabolism I phosphatases in the cell surface of living yeast cells. J. Comp. Cell. Physiol. 32:77-95.

27.Tognoli, L. and E. Marre. 1981. Purification and characterization of a divalent cation-activated ATP-ADPase from pea stem microsomes. Biochim. Biophys. Acta 642:1-14.

28. Traverso-Cori, A., H. Chaimovich, and O. Cori. 1965. Use of $\mathrm{P}^{32}$-labeled nucleotides in the study of the kinetics of potato apyrase. Fifth inter-american symposium on the peaceful application of nuclear energy, Washington, D.C. 69-74.

29.Treuheit, M.J., P.L. Vaghy, and T.L. Kirley. 1992. $\operatorname{Mg}(2+)$-ATPase from rabbit skeletal muscle transverse tubules is 67-kilodalton glycoprotein. J. Biol. Chem. 267:1177711782 .

30. Valenzuela, M.A., J. Lopez, M. Depix, M. Mancilla, A.M. Kettlun, L. Catalan, M. Chiong, J. Garrido et al. 1989. Comparative subcellular distribution of apyrase from animal and plant sources. Characterization of microsomal apyrase. Comp. Biochem. Physiol. B. 93:911-919.

31.Vara, F. and R. Serrano. 1981. Purification and characterization of a membrane-bound
ATP diphosphohydrolase from Cicer arietinum(chick-pea) roots. Biochem. J. 197:637643.

32.Wang, T.F. and G. Guidotti. 1996. CD39 is an ecto-(Ca2+, $\mathrm{Mg} 2+)$-apyrase. J. Biol. Chem. 271:9898-9902

33.Zimmermann, H. 1999. Two novel families of ectonucleotidases: molecular structures, catalytic properties and a search for function. Trends Pharmacol. Sci. 20:231-236.

Received 18 December 2000; accepted 21 March 2001

Address correspondence to:

Guido Guidotti

Department of Molecular and Cellular Biology

Harvard University

7 Divinity Ave.

Cambridge, MA 02138, USA

e-mail: guidotti@fas.harvard.edu

For reprints of this or any other article, contact Reprints@BioTechniques.com 